DOI: $10.20472 / E F C .2019 .012 .010$

\author{
BOŽENA KADEŘÁBKOVÁ \\ University of Economics in Prague, Czech Republic
}

EMÍLIE JAŠOVÁ

Institute for Forcast, Czech Republic

\title{
CHURN ON THE LABOR MARKET IN THE CZECH REPUBLIC
}

\begin{abstract}
:
The aim of this article is to present the differences between the different flows on the labor market in the Czech Republic. The problem is significant economically, socially and politically. The empirical part of the study focuses on the quantification of so-called churn. The specific features of the Czech Republic's churn include the fact that the overall churn has an anti-cyclical character in the Czech Republic, and that in the period of growth of the total churn, the share of wages and salaries in total in GDP at current prices has increased, which is both contrary to the conclusions of world research. The revival of the economy is accompanied by an increase in total churn, but it does not lead to an increase in wages and salaries resulting from company-to-business movements, as would be the case with economic theory.
\end{abstract}

\section{Keywords:}

churn, labour market, wage

JEL Classification: E24, E32, E37 


\section{Introduction}

The traditional concept of labor market analysis consists of a static analysis of aggregates, such as the level of employment and unemployment and their changes over time. The stagnation of these aggregates in absolute or relative terms (e.g., in relation to the population) may obscure fluctuations that are not captured by this static view. Since the 1970s, this approach has been complemented by a dynamic outlook that highlights the existence of simultaneous flows between employment, unemployment and inactivity. A dynamic approach was introduced in a key study by Clark and Summers (1979). A large number of authors, such as Blanchard and Diamonda (1990), Mortensen and Pissarides (1994), Shimer (2005), Hall (2005), Davis, Faberman and Haltiwanger (2006), Bjelland et al. (2008), Elsby, Hobijn and Sahin (2011), Kahn and McEntarfer (2014) etc. From the Czech authors, the themes of labor market flows are eg Duspivová (2011), Kadeřábková and Maleček (2015). In addition to analyzing the above-mentioned flows in labor markets, the term "churn" or "churning" has often been commonly found in world literature. One of the aims of this article is to explain the relationship between churn and other flows in the labor market.

In the part 2, we present two possible approaches to the concept of churn, respectively. churning. In part 3 we quantify the flows in the labor market and apply churn to the conditions of the Czech Republic. Part 4 summarizes the conclusions of the analysis.

\section{Some theoretical definitions of churn/churning}

The term "churn"/"churning" generally refers to the fluctuation of workers within companies. Although individual authors attribute somewhat different definitions to this term, the basic idea remains the same. In a significant study by Lazear and Spletzer (2012), there is a distinction between three types of businesses: expanding, dampening and stagnant. The basic defining factor is the company accepts more employees than they will release. Expanding businesses, by definition, take more workers than they will release and their total recruitment (hires in expanding businesses $-\mathrm{H}_{\mathrm{E}}$ ) can be divided into net recruitment (growth hires - $\mathrm{H}^{\mathrm{G}_{\mathrm{E}}}$ ) and recruitment replacing redundant employees (replacement hires $-H^{R_{E}}$ ). In a similar way, fluctuations in enterprises can be described as attenuation, which forges more employees than they take up. Their total dismissal (total separation - $\mathrm{S}_{\mathrm{c}}$ ) can be divided into net dismissal (separations that decrease the size of the business $-S^{D}$ ) and dismissal, which is replacement the recruitment of workers (replacement separations - $S^{R}$ ). In stagnant firms („Z“ defines zero-change businessses) the dismissal of employees is equal to their recruitment by definition $\left(\mathrm{S}_{z}=\mathrm{H}_{z}\right)$. The entire theoretical design can be written down as follows:

Total recruitment:

Total redundancies:

Recruitment in expanding companies:

Redundancy in attenuation companies:

Recruitment and dismissal in stagnant companies: $\mathrm{H}_{z}=\mathrm{S}_{z}$

$$
\begin{aligned}
& H=H_{E}+H_{C}+H_{Z} \\
& S=S_{E}+S_{C}+S_{Z} \\
& H_{E}=H^{G_{E}}+H^{R_{E}}, \\
& \text { from definition } H^{R_{E}}=S_{E} \\
& S_{C}=S^{D_{C}}+S^{R_{C}}, \\
& \text { from definition } S^{R_{C}}=H_{C}
\end{aligned}
$$


Churn is defined as the recruitment or dismissal of employees in companies that offset each other.

Churn in expanding companies:

$$
\begin{aligned}
& \mathrm{C}_{E}=H^{R_{E}}=S_{E} \\
& C_{C}=H_{C}=S^{R}{ }_{C} \\
& C Z=H_{Z}=S_{Z} \\
& C=C_{E}+C_{C}+C_{Z}
\end{aligned}
$$$$
\text { Churn in stagnant companies: }
$$

Using the churn concept, we can define the overall recruitment and dismissal of employees:

Total recruitment:

$$
\begin{aligned}
& H=H^{G}+C \\
& S=S^{D} C+C
\end{aligned}
$$

Figure 1 illustrates the relationships between the different concepts of labor market flows. Churn is defined here by Lazear and Spletzer (2012). Employees flows then occur either when moving to / from another job, unemployment or inactivity. Total flows are then defined as the sum of the recruitment and dismissal of employees.

The overall change in the number of employees is marked as the difference between total recruitment and redundancy. This indicator is the only representative of the "static" or "traditional" view of the labor market.

\section{Figure 1}

\section{Relationships between selected concepts of labor force flows, Lazure and Spletzer Churn definitions (2012)}

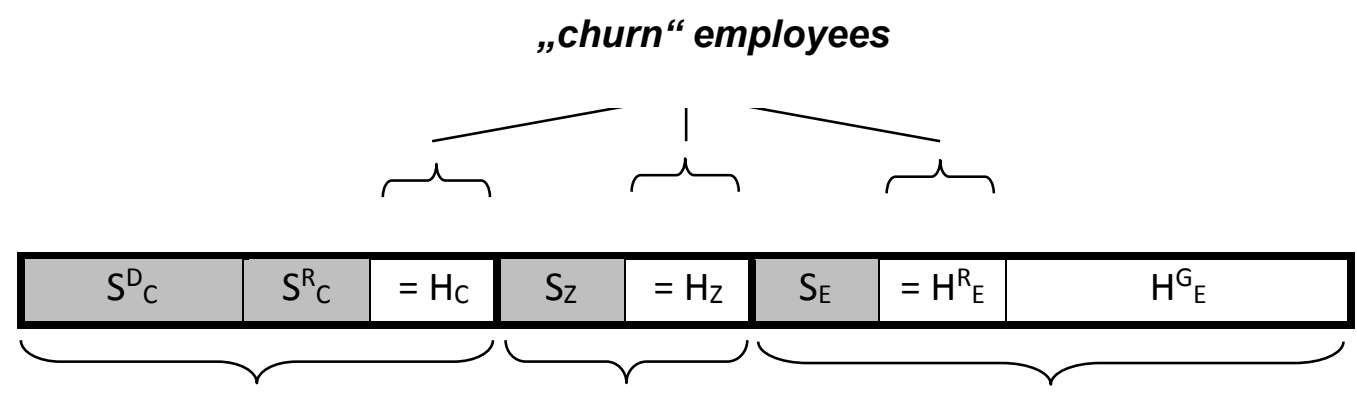

\section{Companies in the attenuation stagnant companies expanding companies}

\section{total emplovees flows}

Source: Own graphical representation based on definitions in Lazear and Spletzer (2012, p. 2-3).

However, this methodology presents only one of many possible definitions of churn. According to the study by Burgess, Lane and Stevens (2000), churn is defined as the difference between employee flows (specified as sum of recruitment and dismissal) and job reallocation (absolute value of change in employment, ie the absolute value of the difference between total recruitment and redundancies). This concept can be written in the following formats:

Total churn:

$$
\mathrm{C}=\mathrm{H}+\mathrm{S}-|\mathrm{H}-\mathrm{S}|
$$

The approach of Burgess, Lane and Stevens (2000) differs from the Lazear and Spletzer (2012) study by not distinguishing between types of businesses. Recall that Figure 1 does not follow all the flows in the labor market as it does not capture the transitions from inactivity to unemployment 
and vice versa and that the churn concept only applies to employees while the overall flows in the labor market include both employees and entrepreneurs.

\section{Quantification of labor market flows and definition of churn in the Czech Republic}

To the above forms 10) and 11) have been completed with data from the Ministry of Labor and Social Affairs (http://portal.mpsv.cz/sz/stat/nz/mes) for the entire national economy. Specifically, the total recruitment of employees $(\mathrm{H})$ was represented by the time series, which the Ministry of Labor and Social Affairs calls the total excluded applicants. The indicator will be called total recruitment when applied to czech conditions. For the net recruitment $\left(\mathrm{H}^{\mathrm{G}_{\mathrm{E}}}\right)$, the sum of time series of newly reported and newly vacated jobs was set and the whole indicator was called the creation of vacancies in the analysis. The total dismissal of employees (S) was represented by the New job announces and the indicator was called total dismissal in the analysis. Net Redundancy $\left(\mathrm{S}^{\mathrm{D}} \mathrm{C}\right)$ was represented by the sum of time series of the Ministry of Labor and Social Affairs Newly Recruited and Newly discontinued jobs. The whole indicator was called job cuts in the analysis. Total churn $(\mathrm{C})$ resp. the total churn indicator was generated by the difference between the total recruitment of $\mathrm{H}$ employees (i.e. the total number of recruited candidates or total recruitment indicator total) and the net recruitment of $\mathrm{H}^{\mathrm{G}_{\mathrm{E}}}$ employees (i.e. the sum of Newly reported and New vacancies or job creation indicator ). In addition, the difference between the total redundancies of $S$ employees (i.e. the newly reported job seeker or total dismissal indicator) and net $S^{D}$ redundancy (i.e. the sum of Newly occupied jobs and Newly discontinued jobs or job cuts indicator).

The methodology was applied to quarterly data. The analysis was performed for the period from 1st quarter 2003 to 2nd quarter 2012, which was further divided into time intervals to map the cyclical development of the problem we were examining. Depending on the development of GDP at current prices (excluding seasonal adjustment), three time intervals were located. As GDP averaged $7.5 \%$ in the first period (from 1st quarter 2003 to 4th quarter 2008), we call it a prerecession period. In the second interval (1st to 4 th quarter of 2009), GDP fell by $2.8 \%$ on average year-on-year and therefore we refer to it as the recession period (in the following Figures 2 to 4 with an arrow). The third time interval (from the 1st quarter of 2010 to the 2 nd quarter of 2012) is characterized by an average year-on-year dynamics of GDP growth of $0.3 \%$, which is why we call it a recovery period. The reason for the end of the research in the first half of 2012 was the decision of the Ministry of Labor and Social Affairs no longer to publish a detailed view on the development of vacancies on its website (http://portal.mpsv.cz/sz/stat/nz/mes). All used time series were seasonally cleaned ${ }^{1}$.

1 The seasonally adjusted series (e.g., for example) was calculated as:

$z_{t}=y_{t} / s_{i}$,

where $S_{i}$ is seasonal factor for $\mathrm{i}$-th quarter is calculated as the average of the values corresponding to the observation for the given quarter (and normalized by the geometric average) and where $x_{t}$ it is calculated as

$x_{t}=\left(0,5 y_{t+2}+y_{t+1}+y_{t}+y_{t-1}+0,5 y_{t-2}\right) / 4$ and $y_{t}$ the original uncleaned series.

Source: EViews (1998). 


\section{Figure 2}

Development of registered unemployment rate (in\%) and total churn (in thousands)

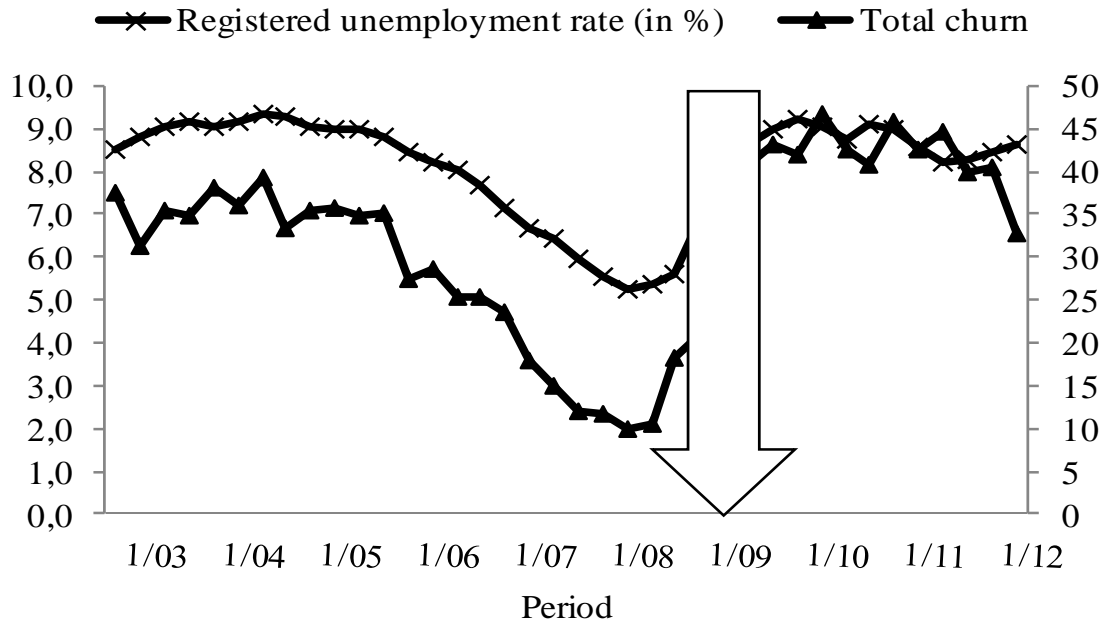

Source: Data of the Ministry of Labor and Social Affairs and own calculation based on the data of the Ministry of Labor and Social Affairs

\section{Figure 3}

Development of the number of employed persons in the national economy (in thousands) and total churn (in thousands)

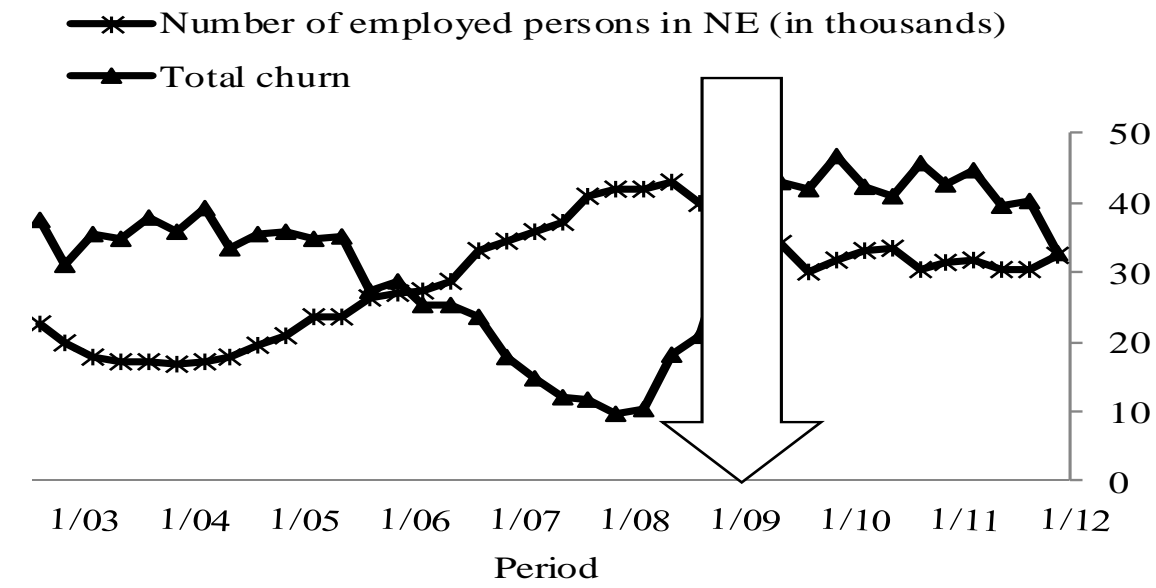

Source: Data of the Czech Statistical Office and own calculation based on data from the Ministry of Labor and Social Affairs

Assuming consistency in labor market measurement methodologies in the Czech Republic and the United States, then by comparing the measurement results we will find the anti-cyclical character of the total churn in the Czech Republic compared to the USA, where there is a pronounced pro-cyclic character of churn. The value of the correlation between the total churn and the registered unemployment rate in the Czech Republic during the whole monitored period was + 0.89 (for the USA in Q1 2001 to Q2 2011 it was - 0.96). The cyclical character of the total churn in the Czech Republic was found only in the 1st quarter to the 4th quarter of 2003 (correlation coefficient value - 0,20) and in the period from 2nd quarter 2011 to 2nd quarter 2012 
(correlation coefficient value - 0,69). In the case of a correlation between the total churn and the number of persons employed, the positive correlation value $(+0.27)$ was obtained in the period from Q1 to Q4 2003. For the whole period (from 1st quarter 2003 to 2nd quarter 2012) the correlation coefficient was -0.49 , unlike the US, where the positive correlation value was +0.43 (from 1st quarter 2001 to 2 nd quarter 2011).

\section{Figure 4}

\section{Development of total recruitment, job creation and total churn (in thousands)}

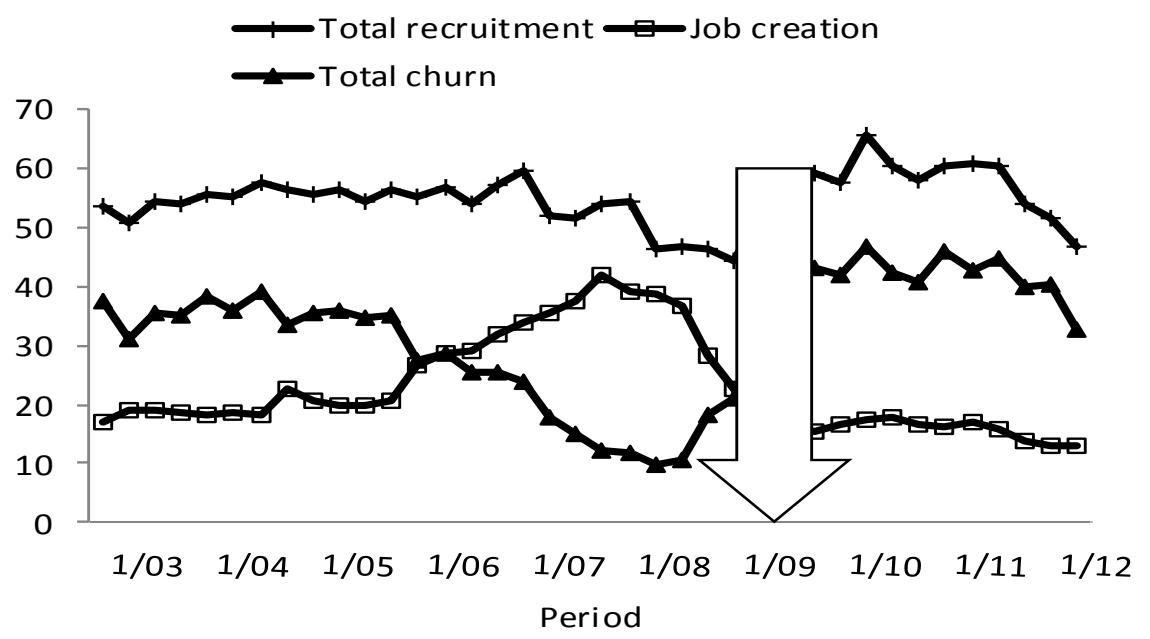

Source: Data of the Ministry of Labor and Social Affairs and own calculation based on the data of the Ministry of Labor and Social Affairs

From the first quarter of 2003 to the first quarter of 2007, total churn accounted for a total of $59.2 \%$ of recruitment (Figure 4). Churn does not increase or reduce overall employment. In the second quarter of 2007 to the first quarter of 2009 , the share of total recruitment fell to $29.7 \%$. In the time span from 2nd quarter 2009 to 2 nd quarter 2012, other companies even passed $72.0 \%$, which represents a significant increase in churn. At the time of the recession in the Czech economy, total churn accounted for $64.1 \%$ of the recruitment, which showed an increase of 14.2 p.p. against the pre-recession period. In the period of subsequent recovery, a further increase in the share of total recruitment churn was shown to total up to $72.7 \%$.

In the time between 1st quarter 2003 and 1st quarter 2007, total churn amounted to an average of 32.8 thousand. In the second quarter 2007 to Q1 2009, its value dropped sharply to 14.5 thousand (i.e. a decline against the value of the previously analyzed period of 18.3 thousand). The total recruitment value decreased during this period from 55.4 thousand to 49,4 thousand. In the final period (2nd quarter 2009 to 2 nd quarter 2012), the total churn was again on average 41.2 thousand. (an increase of 26.7 thousand compared to the average of the period mentioned above), while the value of job creation was on average 15.9 thousand (decrease 19.1 thousand against the previous period). At the time of the recession, the total churn was 34.6 thousand, which was 7.4 thousand more than in the period before it. The recruitment was 53.1 thousand and therefore before the recession, their number decreased by 0.8 thousand. In the period of the subsequent recovery, the growth of total churn was recorded by 7.2 thousand to the value of 41.8 thousand, while the creation of vacancies decreased by 2.3 thousand. to 15.7 thousand. 
The value of the share of total wages and salaries in GDP was 31.3\% in Q1 2003 to Q1 2007. From the following quarter to the 4th quarter of 2008 , this share remained almost stable at $31.6 \%$. From 1st quarter of 2009 to the end of the monitored period (Q2 2012) it increased to 32.1\% (growth by 0.5 p.p. against the last period), which corresponds to the increase of churn in this period by 26.7 thousand workers. From the point of view of the cyclical analysis, during the recession, the share of wages and salaries in total against the pre-crisis period increased by 0.7 p.p. (to $32.1 \%$ ), with the growth of total churn by 7.4 thousand (to 34.6 thousand), which is in contradiction with the US empirical conclusions (The Economist, 2012a). These US findings have assumed that between the onset of the recession in December 2007 and mid-2011, the costs of a reduction in the overall churn on the labor market of $0.4 \%$ of GDP a year. An explanation of developments in the Czech economy may be the effort of employers to attract more highly skilled workers during the recession by, for example, providing further qualification and education. The government, for example, with retraining programs, supports workers to acquire new skills and reintegrate them into work.

However, the subsequent recovery of the Czech economy, which is accompanied by the growth of total churn, did not lead to an increase in the share of wages and salaries on GDP (they are at the same level as during the recession) resulting from movements from company to firm. Recovery of recruitment in the Czech Republic is associated with better prospects for gaining a new job resulting from subjective feelings.

\section{Conclusion}

Analysis of labor force flows is one of the frequent topics of economic literature. Over time, dynamic approaches have evolved alongside static approaches. The churn/churning concept describes the fluctuation of employees in individual enterprises, unlike the total labor flows that relate to all three labor market conditions (employment, unemployment and inactivity).

The growth of employment/the decrease in unemployment does not ensure a healthy labor market. The workers' willingness to accept the risk of moving to new places, i.e. the fluctuation of workers, is significant. Both active employment policy and institutional factors can contribute to increasing fluctuation. More flexible labor markets encourage job change and a better job allocation.

In the empirical part of the study quantification of labor market flows and approximation of churn was performed on the example of the Czech Republic. Specifically, according to the graphical and correlation analysis, the overall churn in the conditions of the Czech Republic has an anti-cyclical character, the pro-cyclic character was found only at the beginning and the end of the monitored period. From the 1st quarter to the 4th quarter of 2003 the value of the correlation coefficient was 0.20 and in the period from 2 nd quarter 2011 to 2 nd quarter 2012 its value was 0.69 . The value of the correlation between total churn and number of employed persons was positive +0.27 only in the first part of the monitored period. For the whole interval the correlation coefficient was -0.49 .

Against the period from 1st quarter 2003 to 1st quarter 2007, the share of overall recruitment fell in the period from 2nd quarter 2007 to 1 st quarter 2009. In the final part of the period under review, $72.0 \%$ went from other companies.

At the time of the recession in the Czech economy, total churn accounted for $64.1 \%$ of the recruitment (up 14.2 p.p. in the pre-recession period). During this period, the drop in recruitment was also accompanied by a downturn in the development of the job creation indicator. In the case of total churn, an increase was recorded against the pre-recession period. In the period of the 
subsequent recovery, the overall share of recruitment churn increased further to $72.7 \%$. The increase in total churn against the recession was the result of a decline in job creation and total recruitment growth.

The share of wages and salaries as a whole in GDP was $31.3 \%$ in the period from 1st quarter 2003 to 1st quarter 2007. In the period of the decline in total churn from Q2 2007 to Q4 2008, the share increased. In the final part of the monitored period, there was a further increase in the share of wages and salaries in total compared to the previous period, which was in line with the evolution of the total churn in this period.

At the time of the recession, the share of wages and salaries overall increased over the period ahead. This is likely to result from greater efforts by employers to attract highly qualified workers into the labor process. The government also plays its part.

The economic recovery in the last part of the monitored period, which is accompanied by the growth of the total churn, did not lead to an increase in the share of wages and salaries on GDP from business to corporate transfers. Recovering recruitment is a factor when deciding employees to leave their old jobs accompanied by a feeling of better prospects for a new job.

\section{References}

Bjelland, M.; Fallick, B.; Haltiwanger, J.; McEntarfer, E. 2008. Employer-to-Employer Flows in the United States: Estimates Using Linked Employer-Employee Data. NBER. Working Paper No. 13867. DOI: 10.3386/w13867.

Blanchard, O. J.; Diamond, P. 1990. The cyclical behavior of the gross flows of US workers. Brookings Papers on Economic Activity. 1990, Vol. 2, pp. 85-143. DOI: 10.2307/2534505.

Clark, K. B.; Summers, L. H. 1979. Labor market dynamics and unemployment: a reconsideration. Brookings Papers on Economic Activity. 1979, Vol. 1, pp. 13-72. DOI: 10.2307/2534304.

DAVIS, S. J.; FABERMAN, R. J.; HALTIWANGER, J. 2006. The Flow Approach to Labor Markets: New Data Sources and Micro-Macro Links. NBER. Working Paper No. 12167. DOI: 10.3386/w12167.

DUSPIVOVÁ, K. 2011. Role zahraničního vlastnictví z hlediska tvorby pracovních míst a fluktuace zaměstnanců. Politická ekonomie. 2011, Vol. 59, No. 6, pp. 759-774. DOI: 10.18267/j.polek.820.

THE ECONOMIST. 2012. Churn for the better, Finance and economics.

THE ECONOMIST. 2012a. Go for the churn. The number of job-to-job moves by American workers tells a bleak story, Finance and economics p. 69.

Elsby, M. W. L.; Hobijn, B.; Sahin, A. 2011. Unemployment Dynamics in the OECD. Tinbergen Institute. Discussion Paper No. 11-159/3.

HALL, R. E. 2005. Job Loss, Job Finding, and Unemployment in the U.S. Economy over the Past Fifty Years. NBER. Working Paper No. 11678. DOI: 10.3386/w11678.

KADEŘÁBKOVÁ, B.; MALEČEK, P. 2015. Churning and Labour Market Flows in the New EU Member States. Procedia Economics and Finance. 2015, No. 30, pp. 372-378. DOI: 10.1016/S22125671(15)01304-0.

KAHN, L. B.; McENTARFER, E. 2014. Employment Cyclicality and Firm Quality. NBER. Working Paper No. 20698. DOI: $10.3386 / \mathrm{w} 20698$.

Lazear, E. P.; Spletzer, J. R. 2012. Hiring, Churn and the Business Cycle. NBER. Working Paper No. 17910. DOI: $10.3386 / \mathrm{w} 17910$. 
Mortensen, D.; Pissarides, C. 1994. Job Creation and Job Destruction in the Theory of Unemployment. Review of Economic Studies. 1994, Vol. 61, No. 3, pp. 397-415. DOI: 10.2307/2297896.

SHIMER, R. 2005. The cyclicality of hires, separations, and job-to-job transitions. Federal Reserve Bank of St. Louis Review. 2005, Vol. 87, No. 4, pp. 493-508.

\section{Internet sources}

\section{Czech statistical office}

GDP in current prices

https://www.czso.cz/csu/czso/hdp cr

Wages and salaries in current prices

https://www.czso.cz/csu/czso/hdp cr

Number of employed in the National Economy

http://www.czso.cz/csu/redakce.nsf/i/statistiky

\section{Ministry of Labor and Social Affairs of the Czech Republic}

Registered unemployment rate

http://portal.mpsv.cz/sz/stat/nz

Jobseekers

http://portal.mpsv.cz/sz/stat/nz/mes

Vacancies

http://portal.mpsv.cz/sz/stat/nz/mes 